\title{
Sea lice prevention strategies affect cleaner fish delousing efficacy in commercial Atlantic salmon sea cages
}

\author{
K. Gentry ${ }^{1, *}$, S. Bui ${ }^{2}$, F. Oppedal ${ }^{2}$, T. Dempster ${ }^{1}$ \\ ${ }^{1}$ Sustainable Aquaculture Laboratory - Tropical and Temperate (SALTT), School of BioSciences, University of Melbourne, \\ Victoria 3010, Australia \\ ${ }^{2}$ Institute of Marine Research, Matre Aquaculture Research Station, 5984 Matredal, Norway
}

\begin{abstract}
Over the last 2 decades, cleaner fishes have been employed to remove external sea lice parasites from Atlantic salmon Salmo salar in sea cages. Norway, Scotland, Ireland, and the Faroe Islands combined now use $\sim 60$ million cleaner fish per year. While small-scale experiments demonstrate the efficacy of cleaner fishes, industrial-scale sea cages have multiple structures and conditions that create different environments, which may impact cleaner fish efficacy and welfare. Here, in commercial sea cages, we investigated if 4 different anti-lice strategies impacted the delousing efficacy, physical condition, and behaviour of cleaner fish (corkwing wrasse Symphodus melops). The strategies tested were: (1) cleaner fishes only; (2) cleaner fishes and functional feed; (3) cleaner fishes, functional feed, and deep lights and feeding; and (4) cleaner fishes, functional feed, deep lights and feeding, and lice skirts. Corkwing wrasse were sampled from 3 cage-level replicates of each anti-lice strategy 3 times over 2 mo. Lice levels on salmon were recorded every 3 to 4 wk. Only $11 \%$ of corkwing wrasse had salmon lice in their gut, with individual wrasse having up to 72 lice in their stomach. Wrasse in cages encircled by lice skirts consumed one-ninth as many lice as those in other anti-lice treatments and had less overall impact on the number of lice per salmon. Fin, skin, mouth and eye condition, K factor, and observed cleaning behaviours of corkwing wrasse were similar across all anti-lice strategies. Our results demonstrate that different in-cage anti-lice strategies altered the magnitude of lice consumption in corkwing wrasse at this site and for this production period. Moreover, while a small proportion of corkwing wrasse appear to target lice as prey, most individual corkwing wrasse were ineffective biological control agents in a full-scale farm setting.
\end{abstract}

KEY WORDS: Biological control · Fish welfare ' Lepeophtheirus salmonis - Lice skirts · Salmo salar $\cdot$ Symphodus melops

\section{INTRODUCTION}

The hunt is on for ethical, effective, and costefficient solutions that will protect the world's most farmed marine fish, Atlantic salmon Salmo salar, from salmon louse Lepeophtheirus salmonis infestations. Salmon lice are ectoparasitic copepods that feed on salmonid tissues, causing lesions which can lead to immunosuppression, osmoregulatory failure,

*Corresponding author: kat.gentry@unimelb.edu.au and even death (Costello 2006, Fast 2014). They proliferate in the dense host populations generated by aquaculture and may spillback to wild fishes with population-level consequences (Krkošek et al. 2013). Treatment with chemotherapeutants dominated salmon lice control for decades until the resistance to most chemotherapeutants emerged (Aaen et al. 2015), and public concern regarding the effects of chemotherapeutants on non-target organisms led to

(C) The authors 2020. Open Access under Creative Commons by Attribution Licence. Use, distribution and reproduction are unrestricted. Authors and original publication must be credited. 
political reform favouring 'green' salmon production (Hersoug 2015). At present, treatments that physically remove lice by heat shock or mechanical abrasion are most common but can be detrimental to salmon welfare (Overton et al. 2019).

Biological control via the use of cleaner fish is an alternative, widely used method for lice control in sea cages (Treasurer 2018). Cleaner fishes (many species of wrasse, e.g. Centrolabrus exoletus, Ctenolabrus rupestris, Labrus bergylta, Symphodus melops, and Tautogolabrus adspersus, and lumpsuckers Cyclopterus lumpus) eat salmon lice directly off the skin of salmon. Wrasses and lumpsuckers were discovered as biological control agents in the 1980s (Bjordal 1988), and in tank trials, wrasse can maintain lice numbers at $<0.5$ lice per salmon when stocked at $5-10 \%$ of salmon numbers (Leclercq et al. 2014). Compared to chemical treatments, cleaner fish are regarded by some as an economically and ecologically sound solution to the salmon lice problem (Liu \& Bjelland 2014). Over 54 million cleaner fishes were stocked in $65 \%$ of Norway's salmon farms in 2017, a 30-fold increase since 2008 (Norwegian Directorate of Fisheries 2018), while $\sim 6.5$ million are stocked each year in Scotland and Ireland (Munro \& Wallace 2017, 2018, Bolton-Warberg 2018).

Compared to tank trials, the evidence basis for the delousing effect of cleaner fishes in commercial-scale sea cages is limited (Overton et al. 2020), with few fullscale studies conducted with suitable replication and a non-confounded experimental design (Table 1). One replicated study found lumpsuckers successfully controlled lice levels on a salmon farm from late autumn to early spring (Imsland et al. 2018), but research over the high lice incidence summer months and across cleaner fish species is lacking. Gut analyses reveal that $14-36 \%$ of lumpsuckers and $16 \%$ of goldsinny wrasse Ctenolabrus rupestris eat lice in sea cages (Deady et al. 1995, Imsland et al. 2014, Eliasen et al. 2018). Variation in delousing efficacy in sea cages may be due to genetics (Imsland et al. 2016), learning and experience (Imsland et al. 2015), or environmental factors such as temperature (Sayer \& Reader 1996) and light (Loew et al. 2016). Furthermore, the additional complexities and large scale of commercial salmon farms may contribute to deteriorating condition (Skiftesvik et al. 2013), low winter survival (Darwall et al. 1992, Sayer \& Reader 1996), increased disease risk (Gulla \& Bornø 2018), and exceedingly high (48-100\%) mortality of cleaner fishes held in commercial net pens (Nilsen et al. 2014, Olsen 2017). At present, it is unclear how an array of relatively new sea lice prevention strategies, which further alter commercial sea cage environments, interact with cleaner fish condition and delousing efficacy (Overton et al. 2020).

Prevention technologies reduce opportunities for louse attachment to salmon. The infectious copepodid stage of salmon lice is positively phototactic and most abundant in the upper surface layer, so a number of prevention strategies encourage deep swimming in salmon (Oppedal et al. 2017). Submerged lights and submerged feeding can draw salmon deeper at night, but not consistently during sunlight hours (Frenzl et al. 2014). Additionally, salmon need to surface to fill their swim bladder (Dempster et al. 2009, Korsøen et al. 2009), so they are still susceptible to lice in surface waters. Alternatively, lice skirts fine mesh nets that encircle sea cages - act as a barrier to salmon lice. Lice skirts are widely used, with $>900$ lice skirts sold by a single company in 2017, with 2 to 3 skirts used depending upon cage size (Nodland 2017). With good conditions, they can reduce lice loads by $30 \%$ (with a $5 \mathrm{~m}$ skirt; Grøntvedt et al. 2018) to $80 \%$ (10 m skirt; Stien et al. 2018). However, lice skirts can reduce dissolved oxygen content in cages (Stien et al. 2012, 2018), which can lead to poor welfare, reduced growth, and altered behaviour of salmon (Oppedal et al. 2011, Oldham et al. 2017, Solstorm et al. 2018). The effects of lice skirts on cleaner fish is unknown. Functional feed is a passive method for prevention of infestation that can lower lice loads on salmon by $20 \%$ compared to standard diets (Jensen et al. 2015). Functional feeds may work by including ingredients that thicken the mucosal cell layer of salmon epidermis, promote healing of damaged tissue, and repel copepods. It is considered a positive potential solution that promotes welfare and incurs little effort by the farmer. Other liceprevention strategies include snorkels, which limit salmon surface access within a narrow tarpaulin tube (Stien et al. 2016), situating new farms in waters with low connectivity (Samsing et al. 2017), fallowing (Werkman et al. 2011), and floating closed containment cages (Nilsen et al. 2017).

Cage-based prevention strategies cause considerable changes to the sea cage environment, to which both salmon and cleaner fishes will respond. For instance, the use of submerged lights and feeding zones can attract salmon, leading to deeper swimming (Frenzl et al. 2014). Similarly, light is likely an important environmental gradient determining cleaner fish distribution, as they use vision to forage and generally occupy shallow habitats (wild corkwing wrasse Symphodus melops, $<5$ m; Quignard \& Pras 1986). In sea cages, submerged lights may draw 


\begin{tabular}{|c|c|c|c|c|c|c|c|c|}
\hline 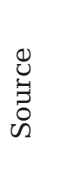 & 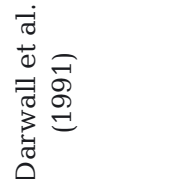 & 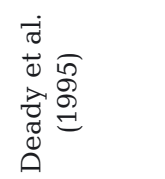 & 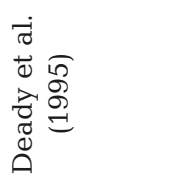 & & 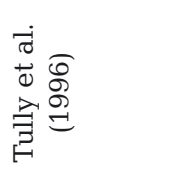 & 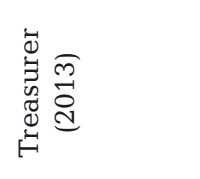 & 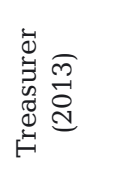 & 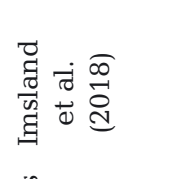 \\
\hline 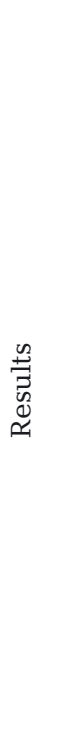 & 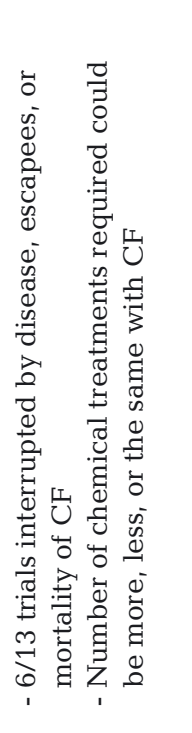 & 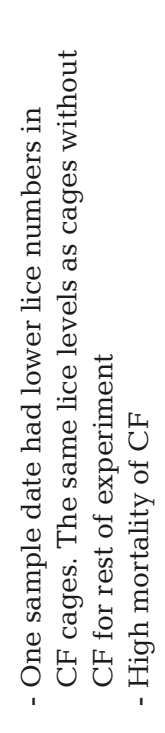 & 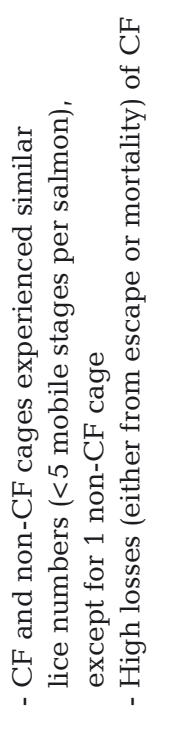 & & 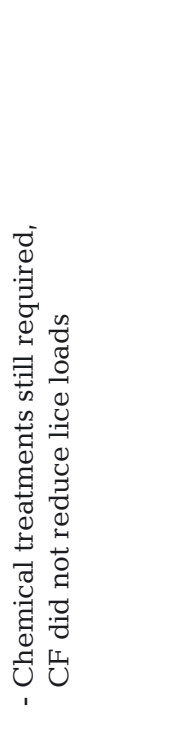 & 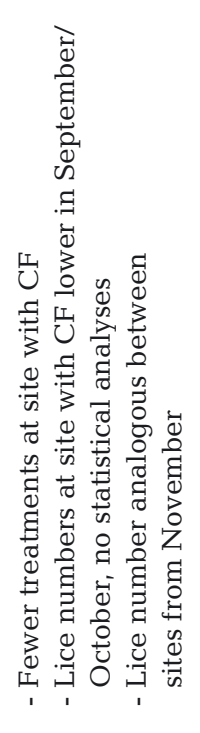 & 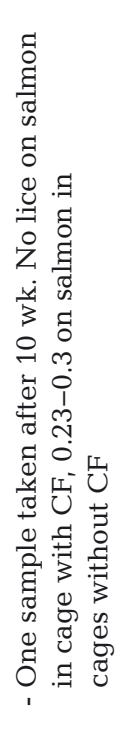 & 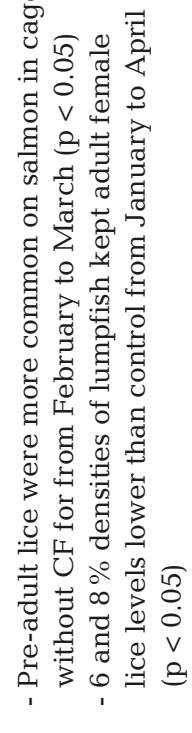 \\
\hline 总 & 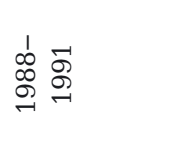 & 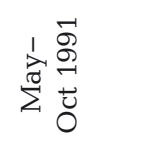 & 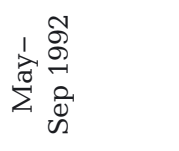 & & 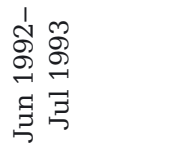 & 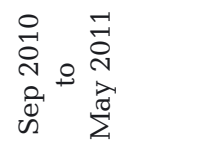 & 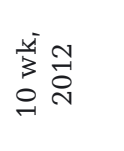 & 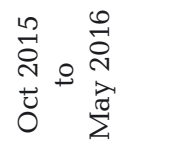 \\
\hline 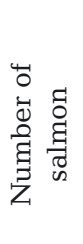 & 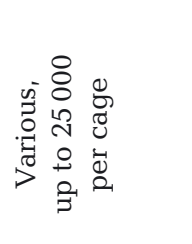 & 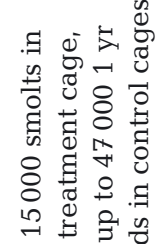 & 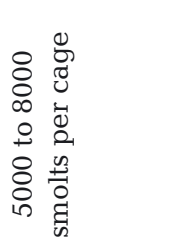 & & 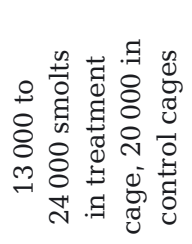 & 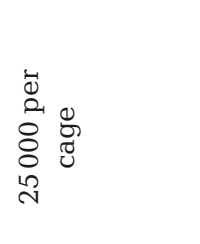 & 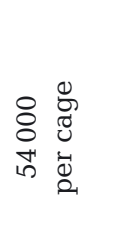 & 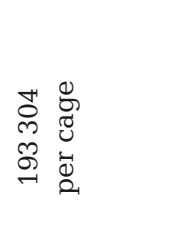 \\
\hline 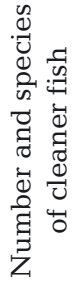 & $\begin{array}{l}0 \\
0 \\
0 \\
0 \\
0 \\
3 \\
0 \\
0 \\
0 \\
0 \\
0 \\
0\end{array}$ & 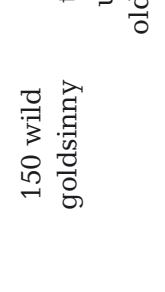 & 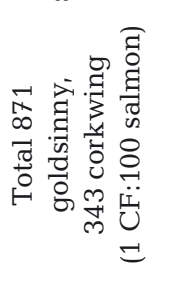 & & 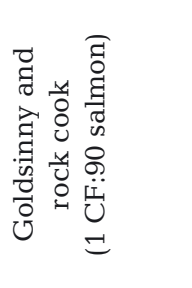 & 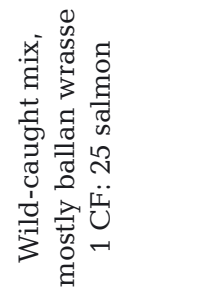 & 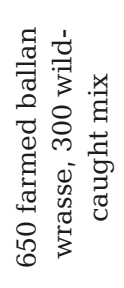 & 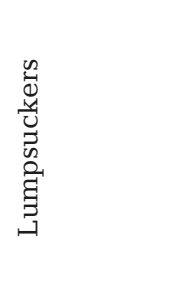 \\
\hline 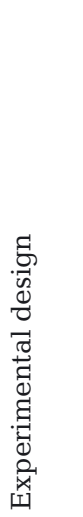 & 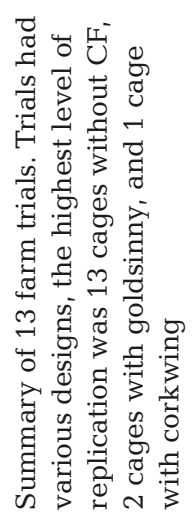 & 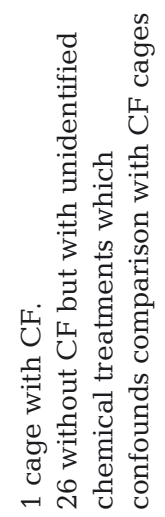 & 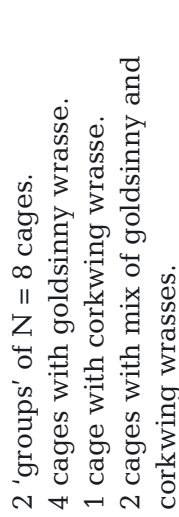 & 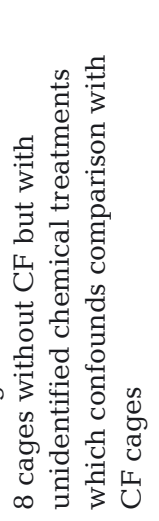 & 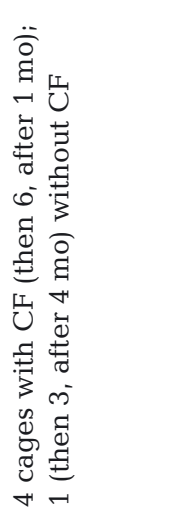 & 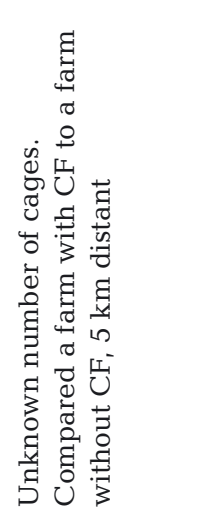 & 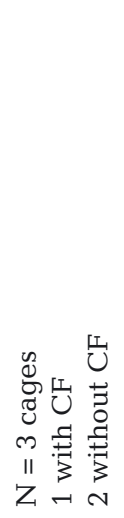 & 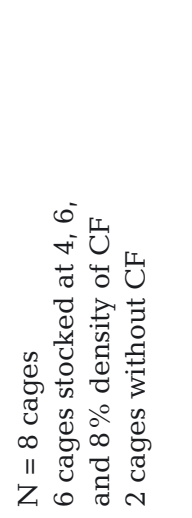 \\
\hline
\end{tabular}


cleaner fishes deeper and extend lice-hunting hours. However, substantial improvements to delousing may be limited by lack of shelter, given that hides are often not placed near lights and do not extend the full depth of the sea cage. Lice skirts can reduce surface dissolved oxygen saturation (Stien et al. 2012), and salmon can swim deep to avoid hypoxic water (Oldham et al. 2017). Cleaner fishes may respond similarly, but lice skirts also reduce surface flow (Frank et al. 2015), and cleaner fish may prefer shallow, lowflow water that mimics their wild habitats (Skiftesvik et al. 2015, Yuen et al. 2019), leading to salmon swimming at depth and cleaner fishes near the surface, thus reducing encounter rates. Furthermore, if functional feed successfully lowers the lice load on salmon, cleaner fishes will have fewer opportunities to consume lice. Each prevention strategy could reduce the cleaner-host encounter rate and limit opportunities to interact with and delouse salmon.

Prevention strategies may also impact cleaner fish welfare. In standard sea cages, cleaner fish condition worsens with time (Skiftesvik et al. 2013). With lice skirts, this may be exacerbated if low oxygen levels decrease fish metabolism and impair foraging behaviour. To counter poor cleaner fish welfare, the industry has assembled best practice procedures (FHF 2016). The procedures stipulate that farmers must feed cleaner fishes regularly, a practice now widely implemented (e.g. all Mowi farms; Henrik Trengereid pers. comm). If anti-lice strategies are effective, and cleaner fishes rely on lice as the principal component of their diet, then condition may decrease. Moreover, current best practice procedures do not account for the impact of new sea cage technologies.

Here, in a replicated commercialscale trial, we compared the delousing efficacy, physical condition, and behaviour of corkwing wrasse $S$. melops, a widely used wild-caught wrasse in Norway, under different lice prevention strategies. This is important because innovative prevention technologies change the sea cage environment, and farmers must demonstrate that cleaner fishes remain effective in removing lice and that their welfare is secured in new cage arrangements. By understanding how cleaner fishes deal with the complexities of a full-size salmon farm, the industry can improve cleaner fish survival and welfare and lower lice infestation rates. Achieving this will subsequently reduce the economic, welfare, and environmental costs of alternative sea lice control measures.

\section{MATERIALS AND METHODS}

\subsection{Location, experimental design, and environmental conditions}

The experiment was conducted at the Centre for Aquaculture Competence's full-scale research and development facility at Vindsvik, in Jøsenfjorden, western Norway $\left(\sim 59^{\circ} \mathrm{N}\right)$ from 25 August (Day 1) to 11 October (Day 49) 2017. A specific animal ethics approval was not required under Norwegian law, as normal production procedures were followed. As cleaner fish are part of standard production (used in $65 \%$ of cages in Norway; Norwegian Directorate of Fisheries 2018) and were present in all cages at this site, their use was not regarded as an experimental treatment. Sampling of fish with acceptable humane endpoints to determine their welfare status or sample organs is within animal welfare regulations as this forms part of normal farming operations. The site was operational since September 2016, with all antilice strategies (see below) in place by January 2017 , with continuous monitoring of the salmon for a 13 mo period (Bui et al. 2020). This full-scale farm has 12 circular sea cages that are $120 \mathrm{~m}$ in circumference and $35 \mathrm{~m}$ deep, arranged in 2 rows parallel to the coastline (Fig. 1a,b). Each sea cage contained 25000

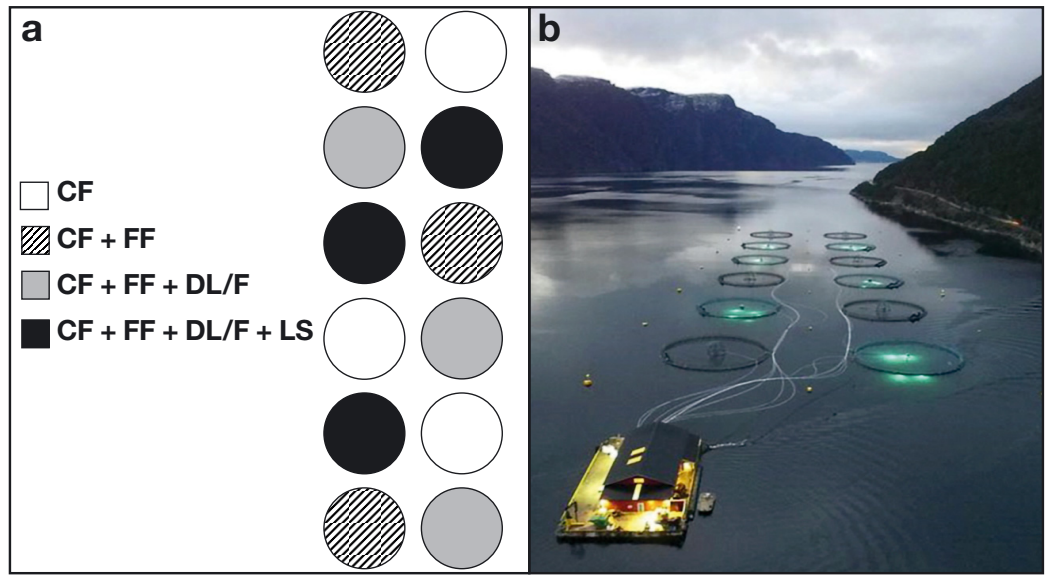

Fig. 1. (a) Diagrammatic representation of the Vindsvik study site and experimental design. Each circle represents a $120 \mathrm{~m}$ circumference sea cage, with shade representing anti-lice strategy. Strategies were allocated to sea cages in a randomised block design. CF: cleaner fish, FF: functional feed, DL/F: deep light and deep feeding, LS: lice skirts. (b) Aerial view of the study site at dusk with underwater light treatments clearly visible in cages 
Atlantic salmon (mean $\pm \mathrm{SE}, 1.9 \pm 0.08 \mathrm{~kg}$ ) and $\sim 5000$ cleaner fishes. New wild-caught cleaner fishes were added to cages when mortality estimates were high, as determined by the site manager (see Table S1 in the Supplement at www.int-res.com/articles/suppl/ q012p067_supp.pdf). At the time of this study, corkwing wrasse $(\sim 84 \%$ of all cleaner fishes caught in pots) were the most abundant species, but lumpsuckers Cyclopterus lumpus ( $<1 \%)$, rock cook Centrolabrus exoletus $(<1 \%)$, goldsinny $(\sim 4 \%)$, and both wild and farmed ballan wrasse Labrus bergylta $(\sim 12 \%)$ were also present. Three hides for cleaner fish shelter ( 1 $\mathrm{m}$ diameter) made of black plastic strips and extending from the surface to $6 \mathrm{~m}$ depth hung in each cage.

One of 4 anti-lice strategies was applied to each of 3 replicate sea cages ( $\mathrm{N}=12$ sea cages): (1) cages containing cleaner fishes and salmon that were fed a standard salmon feed (Skretting Optiline, $9 \mathrm{~mm}$ ), henceforth referred to as cleaner fish only; (2) cages containing cleaner fishes and salmon that were fed a functional feed (Skretting's Shield, $9 \mathrm{~mm}$ ); (3) cages containing cleaner fishes and salmon that were fed functional feed, plus deep lights (Aurora SubLED Combi, $120 \mathrm{~W}$ UV LED light, violet colour, at 5-7 $\mathrm{m}$ depth; AKVA Group) and deep feeding (AKVA SubFeeder; AKVA Group); and (4) cages containing cleaner fishes and salmon that were fed functional feed, plus deep lights/feeding, plus a skirt to prevent sea lice (mesh size $350 \mu \mathrm{m}, 6 \mathrm{~m}$ deep, Norwegian Weather Protection Aquaculture). Treatments were allocated to sea cages using a randomised block design (Fig. 1a,b).

Cleaner fishes and salmon in all cages were fed using standard husbandry procedures during the experiment, including supplementary feed for cleaner fish. Environmental profiles of the water column were collected from a reference point on the farm using a conductivity, temperature and depth (CTD) sensor (Model SD204, SAIV AS, Norway). The CTD probe was set to measure every minute, moving between 0 and $40 \mathrm{~m}$ in depth.

\subsection{Swimming depths of Atlantic salmon and cleaner fish}

The swimming depth distributions of salmon in each cage were continuously recorded using a PCbased echo integration system (CageEye). The transducers were positioned below the centre of each cage at $35 \mathrm{~m}$ depth, facing upwards with a $15^{\circ}$ acoustic beam. Full details of the system are given by Bjordal et al. (1993). Echo intensity, which is directly propor- tional to fish density, was recorded at $0.5 \mathrm{~m}$ depth intervals from 0 to $35 \mathrm{~m}$ and converted to relative echo intensity in each interval. A mean value of the echo observations per minute (60 pings $\mathrm{min}^{-1}$ ) was recorded and used to calculate a relative density on a scale from 0 to 1 . All data were condensed to cage averages per $1 \mathrm{~m}$ depth interval, to create a mean salmon school depth, prior to analysis.

As the echosounder system did not provide data on wrasse swimming depths, we directly observed wrasse with an ROV prior to the first sampling period during daytime to set the depth for wrasse pots.

\subsection{Delousing efficacy of cleaner fish}

Delousing efficacy was measured in 2 ways: the number of lice per corkwing wrasse gut, and a calculated 'cleaner fish effect' (CFE). To determine the number of lice consumed by wrasse, 8 to 10 corkwing wrasse from each sea cage were caught using prawn-baited wrasse pots deployed from 09:00 to $12: 30 \mathrm{~h}$ at $7 \mathrm{~m}$ depth, then euthanised with an overdose of tricaine methanesulfonate (Finquel ${ }^{\circledR}$, Scan Aqua $\mathrm{AS} ; \mathrm{g} 10 \mathrm{l}^{-1}$ ). Each wrasse was dissected and their gut contents visually inspected. The number of salmon lice were counted, scales were recorded as present or absent, and the other content was identified as either crustaceans, feed, algae, completely digested/unidentifiable, or empty.

Cleaner wrasse primarily consume the mobile stages of lice (preadult and adult) as they are large enough to detect (Skiftesvik et al. 2013). Thus, to measure $\mathrm{CFE}$, we compared the expected mean number of mobile lice salmon ${ }^{-1}(\mu$ (expected mobile) $)$ to the actual mean number of mobile lice salmon ${ }^{-1}$ ( $\mu$ (actual mobile)). Assuming no chemical delousing and equal attrition across cages, the $\mu$ (expected mobile) for sample $t$ should equal the $\mu$ (actual mobile) at sample time $t$, unless cleaner fishes are removing mobile lice. Thus, a high CFE occurs when cleaner fishes consume many lice, whereby there is a low $\mu$ (actual mobile) compared to high $\mu$ (expected mobile).

To calculate $\mu$ (expected mobile) ${ }_{t}, 20$ salmon were collected from every cage using a $3 \mathrm{~m}$ ring net pulled up from $\sim 5 \mathrm{~m}$ near the centre of the cage 3 wk before the experiment (2 August) and close to Sample 1 and Sample 2 (28 August and 13 September). Salmon were not sampled at Sample 3 (6 October) due to lice treatments. Each sample spanned over 3 consecutive days (see Table S1). Salmon were transferred using a dip net to a bath containing an overdose of anaesthesia. After euthanasia, individuals were assessed 
for their infestation status whereby lice were counted and staged as chalimus I, chalimus II, preadult I, preadult male, preadult female, adult male, adult female, adult female with eggstrings, or Caligus elongatus. Then, the mean number of lice per salmon across replicate cages was determined for each lice management strategy. At $12.5^{\circ} \mathrm{C}$ (the average temperature during the experimental period), it takes $3 \mathrm{wk}$ for attached lice (i.e. copepodids, chalimus 1, and chalimus 2) to become mobile lice (i.e. pre-adult 1 stage and later) (Samsing et al. 2016; Hamre et al. 2019), when they can be consumed by cleaner fishes (Brooker et al. 2018). Thus, to calculate $\mu$ (expected mobile) $t_{\text {, }}$ we used the following formula:

$$
\begin{aligned}
\mu(\text { expected mobile })_{t} & =\mu(\text { attached })_{t-3 \text { weeks }} \\
& +\mu(\text { actual mobile })_{t-3 \text { weeks }}
\end{aligned}
$$

where $\mu$ (expected mobile $)_{t}$ is the expected mean number of mobile lice per salmon for that lice management strategy at sample time $t$, assuming no mortality or emigration; $\mu$ (attached $)_{t-3 \text { weeks }}$ is the mean number of attached lice salmon ${ }^{-1}$ for that management strategy, $3 \mathrm{wk}$ prior to sample time $t_{i}$ and $\mu$ (actual mobile $)_{t-3 \text { weeks }}$ is the mean number of mobile lice per salmon for that management strategy, $3 \mathrm{wk}$ prior to sample time $t$.

To calculate the CFE for each lice management strategy and sample point, we used the following formula:

$$
\mathrm{CFE}=\mu(\text { expected mobile })_{t}-\mu(\text { actual mobile })_{t}
$$

where $\mu$ (expected mobile $)_{t}$ is the expected mean number of lice per salmon for that lice management strategy at sample time $t$, assuming no mortality or emigration; $\mu$ (actual mobile) ${ }_{t}$ is the actual mean number of mobile lice per salmon for that management strategy at sample time $t$, which was recorded from the physical inspection of experimental fish.

\subsection{Physical condition of cleaner fish}

Length $(L, \pm 0.05 \mathrm{~cm})$ from snout to caudal fin and weight $\left(W_{1} \pm 0.05 \mathrm{~g}\right.$ ) were measured, from which Fulton's condition factor $\left(K=W /[L]^{3} \times 100\right)$ was calculated to estimate corkwing wrasse condition. Eye, fin, skin, snout, opercula and gill damage were recorded as present or absent, as were deformities.

\subsection{Behaviour of cleaner fish}

In each sea cage at all 3 sampling times, behaviour was filmed for $15 \mathrm{~min}$ on 2 underwater cameras (Go-
Pro Hero 5) at $7 \mathrm{~m}$ depth. A remotely operated underwater vehicle (Deep Trekker DTG2) checked the cameras were not tangled and that one was facing a hide. Video recordings were analysed afterwards to determine the prevalence of the following behaviours: swimming with salmon, inspecting salmon, feeding on lice, alternative feeding, salmon avoidance, inter/ intra-specific aggression (see Table S2). Behaviours were counted as present or absent in each 15 min film replicate.

\subsection{Statistical analyses}

To determine if corkwing wrasse lice consumption differed between prevention strategies, a zeroinflated generalised linear mixed model (function 'glmmTMB' in package 'glmmTMB', RStudio v. 3.4.2; R Core Team 2018) analysed lice count per corkwing gut data, where group was fixed and cage and sample time were random effects. As there were more fish with several or no lice in their guts, and only a few with 10 s of lice gut ${ }^{-1}$, a negative binomial family was specified.

CFE fitted a normal distribution so was analysed using a standard linear model (function ' $1 \mathrm{~m}$ '), with both group and sample as fixed effects. Sample was treated as a fixed effect because there were not enough levels to treat it as a random effect.

To test if corkwing wrasse condition differed between different anti-lice strategies, $K$-scores fitted a normal distribution and therefore were analysed using a linear mixed-effects model estimated by maximum likelihood, with group as a fixed effect and cage and sample time as random effects (function 'lmer' in 'lme4').

To test if physical damage differed between prevention strategies, fin, skin, eye, snout, gill, and opercula damage were fitted to a generalised linear mixed model with a binomial distribution, where group was a fixed effect and sample time and cage were random effects (function 'glmmTMB' in package 'glmmTMB', R). Stomach contents and behaviour data were analysed using the same model and distribution.

Mean school depth was calculated for each replicate cage from 30 August to 23 September. A 1way ANOVA (function aov, R) was used to test if salmon schooled at different depths when subjected to different lice-prevention strategies. Post-hoc analysis was conducted using Tukey's test (function TukeyHSD, R) where $\mathrm{p}<0.05$ was considered statistically significant. 
Homogeneity of variance and normality of errors were confirmed with visual inspection of residual plots for both $K$-score and CFE (function 'plot', R). All models were compared to corresponding null models, excluding group as a factor in likelihood ratio tests (function 'anova', R) to attain p-values. Where $p<0.05$, Tukey's test (function 'lsmeans' in package 'Ismeans', Ri Lenth 2016) generated adjusted p-values using least squares means to identify significant differences between groups.

\section{RESULTS}

\subsection{Environmental conditions}

Between 25 August (Day 1) and 11 October 2017 (Day 49), salinity (Fig. 2a) from 5 to $35 \mathrm{~m}$ depth ranged between 26 and 34 PSU. From 0 to $5 \mathrm{~m}$, the first and last $3 \mathrm{wk}$ were marked by periods of brackish water, reaching a minimum of 12 PSU. For most of this study period, there was a thermocline of warm water $\left(>14^{\circ} \mathrm{C}\right)$ between 0 and $15 \mathrm{~m}$ and cooler water below $15 \mathrm{~m}$ (Fig. 2b). In the fifth week, the water temperature was uniformly warm $\left(14-15^{\circ} \mathrm{C}\right)$ throughout the water column. During the last 2 wk of the study period, the mean temperature dropped to $12^{\circ} \mathrm{C}$, with coldest temperatures occurring below $25 \mathrm{~m}$ and at the surface. Dissolved oxygen concentration generally remained above $85 \%$ in the first $5 \mathrm{~m}$ of water throughout the trial, while deeper waters experienced levels $\sim 70 \%$ saturation (Fig. 2c). The third week was characterised by slightly lower dissolved oxygen levels ( $\sim 60 \%)$ from 10 to $30 \mathrm{~m}$. This was followed by $10 \mathrm{~d}$ of high oxygen saturation (>75\%) across all depths, before levels once again stratified with high dissolved oxygen at the surface and $~ 70 \%$ at depth.

\subsection{Swimming depths of Atlantic salmon}

An overall difference in the mean swimming depth of salmon between anti-lice strategies was observed throughout the experimental period $(\mathrm{df}=3, F=6.4$, $\mathrm{p}=0.02)$. On average, salmon swam far deeper in cages surrounded by lice skirts (mean \pm SE: $11.1 \pm$ $1.9 \mathrm{~m})$ compared to $\mathrm{CF}(4.1 \pm 0.04 \mathrm{~m})$ and $\mathrm{CF}+\mathrm{FF}$ $(4.2 \pm 0.5 \mathrm{~m})$ cages (Fig. 3). Salmon subjected to deep lights but not lice skirts also swam shallower (6.6 \pm $0.8 \mathrm{~m}$ ) than those in skirt-encircled cages, but the post-hoc Tukey's test revealed there was no significant difference between these 2 cage types $(p=0.1)$.
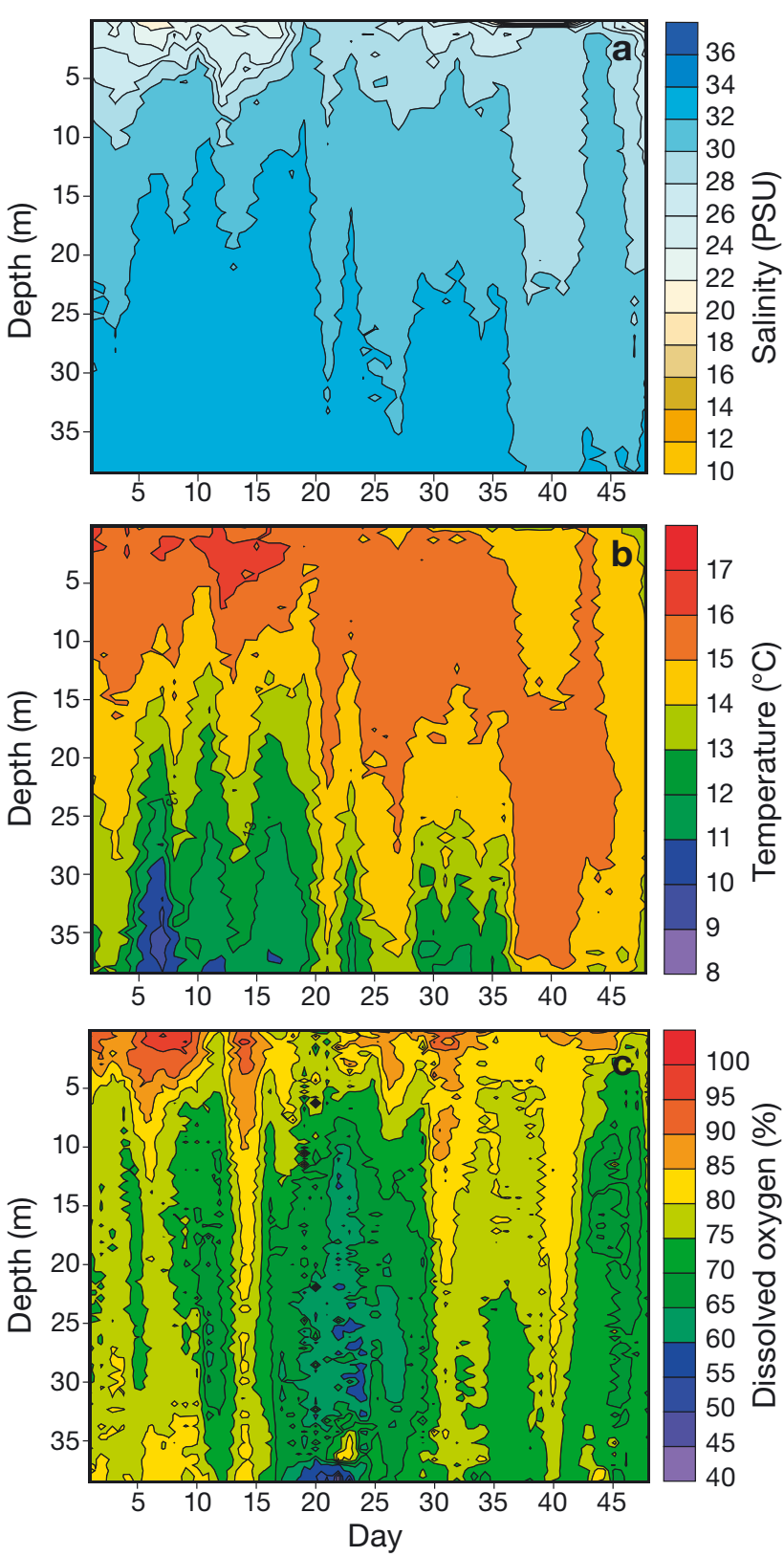

Fig. 2. (a) Salinity, (b) water temperature and (c) dissolved oxygen content (\% saturation) from 0 to $35 \mathrm{~m}$ depth at Vindsvik CAC from 25 August (Day 1) to 11 October 2017 (Day 49)

\subsection{Cleaner fish stocking levels and salmon lice levels among anti-lice strategies}

At the start of Sample 1, an average of $6843-7920$ cleaner fish were stocked onto the 4 anti-lice strategies (see Table S1 in the Supplement). Cleaner fish continued to be stocked throughout the experiment, so that numbers increased to 6843 - 9564 at Sample 3. Cleaner fish mortalities were recorded in each cage as the number of dead cleaner fish retrieved from the 


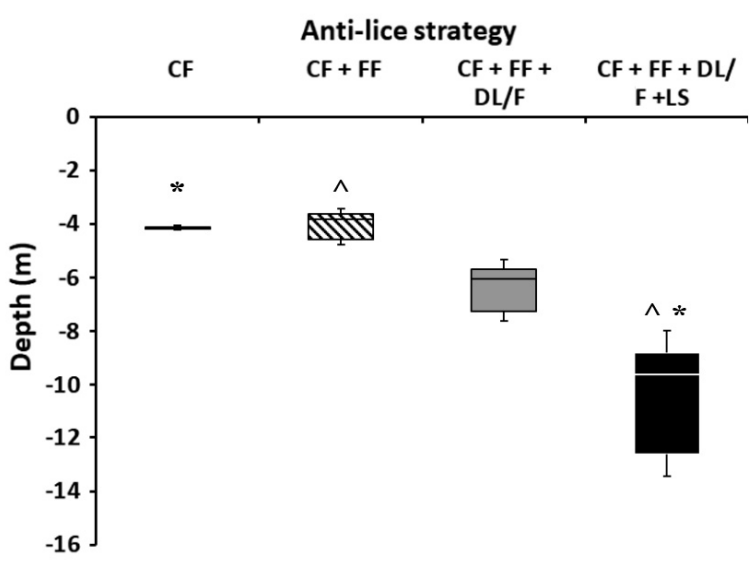

Fig. 3. Boxplots of mean salmon schooling depth for each antilice strategy, showing the third quartile (Q3) and first quartile (Q1) range of the data at the Vindsvik site from 30 August (Day 6) to 23 September (Day 30) 2017. CF: cleaner fish, FF: functional feed, DL/F: deep light and deep feeding, LS: lice skirts. Different symbols $\left({ }^{*}\right.$ and ${ }^{\wedge}$ ) indicate significant differences revealed by Tukey's test
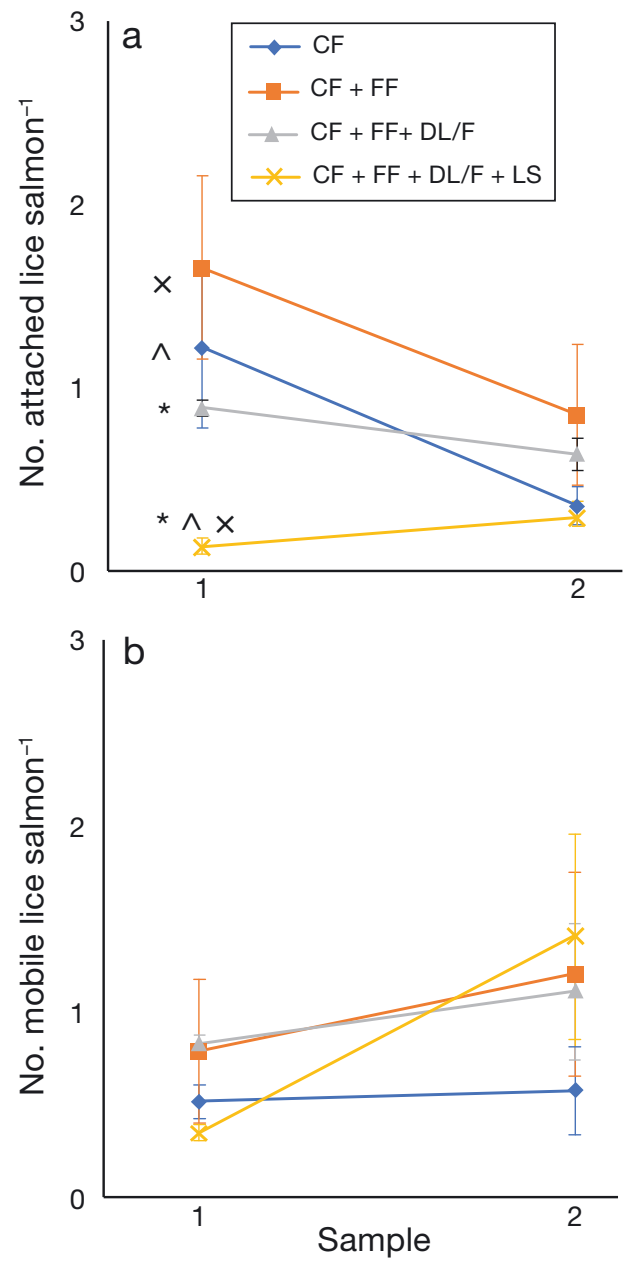

Fig. 4. Mean $( \pm \mathrm{SE})$ number of (a) attached and (b) mobile lice per salmon in each treatment at Samples 1 and 2. See Fig. 3 for more details salmon mortality net placed in the bottom of each cage (Fig. S1). At Sample 1, mobile lice per salmon averaged 0.57 to 1.4 , increasing to 1.28 to 2.64 in Sample 2 (Fig. 4b). Attached salmon stages ranged from 0.1 to 1.7 in Sample 1 and from 0.3 to 0.9 in Sample 2 (Fig. 4a). Mean attached lice per salmon differed at Sample 1 only, with lice skirt treatments lower than all other treatments. Mean mobile lice per salmon did not differ among treatments at either time. Lice abundances were not estimated in Sample 3 due to lice-control treatments undertaken by the farm staff (Table S1).

\subsection{Delousing efficacy of cleaner fish}

Corkwing wrasse in lice skirt-encircled sea cages were the poorest delousers compared to other antilice strategies. This result was consistent over both measures of delousing efficacy: the number of lice in guts (Fig. 5) and CFE (Fig. 6).

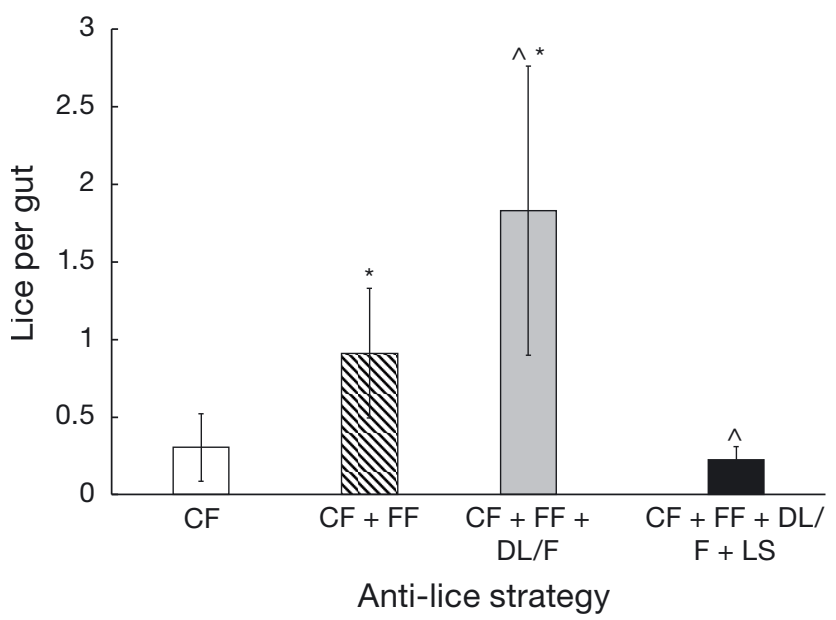

Fig. 5. Number of lice (mean $\pm \mathrm{SE}$ ) per corkwing wrasse gut for each anti-lice strategy. See Fig. 3 for more details

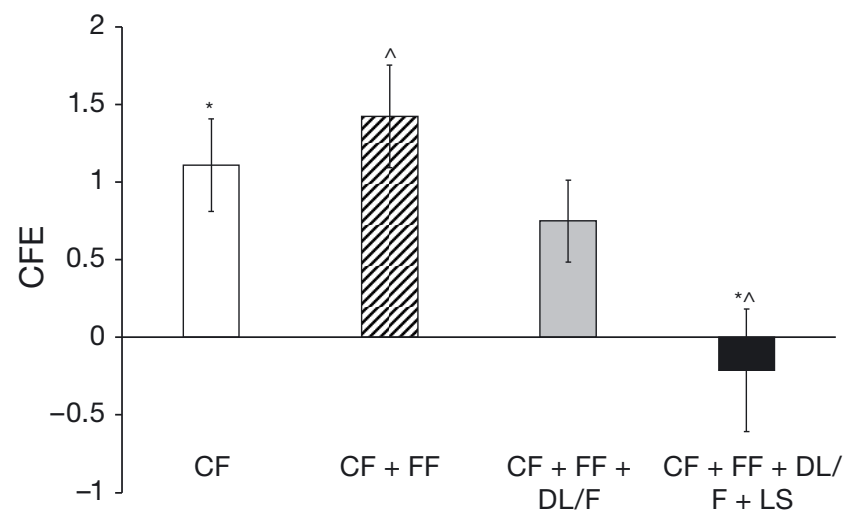

Anti-lice strategy

Fig. 6. Cleaner fish effect (mean $\pm \mathrm{SE}$ ), calculated as the mean predicted number of lice minus the mean actual number of lice for each anti-lice strategy. See Fig. 3 for more details 
Of all fish sampled across treatment groups, $11 \%$ of corkwing wrasse consumed lice. The mean $( \pm \mathrm{SE})$ number of lice per corkwing gut were $0.3( \pm 0.2)$, $0.9( \pm 0.4), 1.8( \pm 0.9)$, and $0.2( \pm 0.0)$ for cleaner fish only, cleaner fish plus functional feed, cleaner fish plus functional feed plus deep lights/feeding, and cleaner fish plus functional feed plus deep lights/ feeding plus lice skirt strategies, respectively (Fig. 5). The full model indicated a strong overall effect of anti-lice strategy on the number of lice in corkwing guts. Post-hoc pairwise testing revealed that this overall effect was driven by differences between the lice skirt treatment and both functional feed $(z=2.8$, $\mathrm{p}=0.001$ ) and functional feed plus deep lights/ feeding $(z=5.1, p<0.0001)$ treatments.

Using the CFE estimate, the most effective cleaner fishes were in sea cages with cleaner fish plus functional feed (mean $\pm \mathrm{SE} \mathrm{CFE}=1.4 \pm 0.33$ ). There was no difference between the cleaner fish only (CFE = $1.1 \pm 0.30$ ), cleaner fish plus functional feed plus deep lights/feeding $(\mathrm{CFE}=0.8 \pm 0.26)$, and lice skirt $(\mathrm{CFE}=$ $-0.2 \pm 0.40$ ) strategies (Fig. 6). Comparison of full and reduced models indicated an effect of anti-lice strategy $(F=5.1, \mathrm{p}=0.009)$ and no effect of sampling time $(F=2.6, \mathrm{p}=0.12)$. Post-hoc pairwise comparison revealed the effect was driven by differences between the lice skirt-encircled cages and the cleaner fish only $(\mathrm{p}=0.04)$ and between the lice skirtencircled cages and cleaner fish plus functional feed $(p=0.008)$ treatments.

\subsection{Physical condition of cleaner fish}

The different anti-lice strategies had the same impact on corkwing wrasse physical condition. Condition ( $K$-score: $\chi^{2}=5.9, \mathrm{p}=0.1$, general model: [weight in $\mathrm{g}$ ] $=0.014$ [length in $\mathrm{cm}]^{3}, \mathrm{R}^{2}=0.9$ ), fin $\left(\chi^{2}=2.2, \mathrm{p}=0.5\right)$, skin $\left(\chi^{2}=1.6, \mathrm{p}=0.7\right)$, eye $\left(\chi^{2}=\right.$ $1.10, \mathrm{p}=0.8)$, and snout $\left(\chi^{2}=2.0, \mathrm{p}=0.6\right)$ damage were similar across anti-lice strategies. Gill and operculum damage were too rare (19 and 12 incidences respectively) to model reliably. Fin damage was commonly recorded on corkwing wrasse $(75 \%$ prevalence), followed by skin $(28 \%)$, eye $(13 \%)$, operculum (4\%), and snout (3\%) damage (Fig. 7 ).

\subsection{Gut contents of cleaner fish}

The most common food in corkwing guts across cage groups was completely digested, unidentifiable matter $(38 \%)$, followed by algae $(29 \%)$, crustaceans

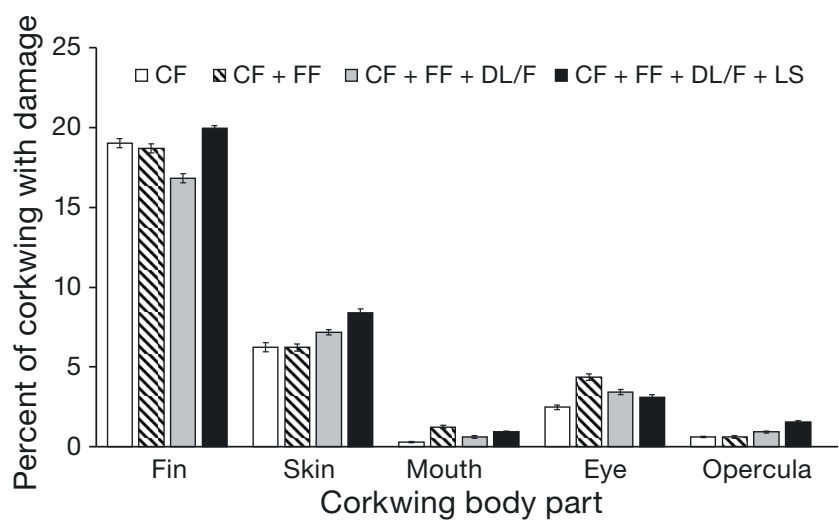

Fig. 7. Percent (mean \pm SE) of corkwing wrasse with fin, jaw, skin, eye and opercula damage for each anti-lice strategy. See Fig. 1 for abbreviations

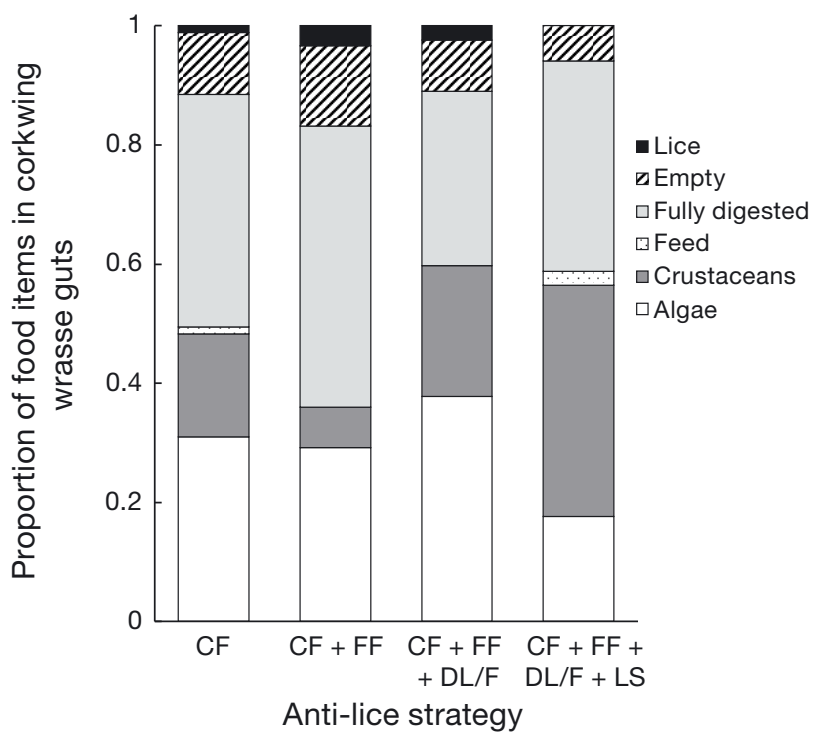

Fig. 8. Proportion of corkwing wrasse with primarily algae, crustacea, feed, lice, fully digested/unidentifiable content or nothing in their gut for different lice prevention strategies. See Fig. 1 for abbreviations

$(21 \%)$, lice $(1.8 \%)$, then feed $(0.9 \%)$ (Fig. 8$)$. Ten percent of guts were empty. Crustaceans, predominantly Caprellid amphipods, were 5 -fold less important prey items for corkwing in the cleaner fish plus functional feed group compared to corkwing in the lice skirtencircled group $(z=-3.6, p=0.001)$. There were no other differences between main food consumed and anti-lice regime. In total, $20 \%$ of corkwing wrasse had scales in their guts and anti-lice strategy did not affect prevalence of scales $\left(\chi^{2}=3.0, p=0.4\right)$.

\subsection{Behaviour of cleaner fish}

We detected no differences in cleaner fish behaviours between anti-lice strategies (lice feeding: $\chi^{2}=3.6$, 
$\mathrm{p}=0.3$; inspection: $\chi^{2}=4.8, \mathrm{p}=0.2 ;$ swimming near salmon: $\chi^{2}=2.9, \mathrm{p}=0.4$; alternate feeding: $\chi^{2}=1.9$, $\mathrm{p}=0.6$; avoiding salmon: too infrequent to model reliably). The most commonly observed behaviour in sea cages across treatments over 10 observed hours was swimming near salmon (89 instances), followed by alternative feeding (45 instances), inspecting salmon for lice (25 instances), avoiding salmon (8 instances), and feeding on lice (6 instances).

\section{DISCUSSION}

In an experiment on a commercial-scale Atlantic salmon farm, we tested if cleaner fish delousing efficacy differed between anti-lice strategies. Based on stomach contents and estimations of CFE, cleaner fishes were least effective when used with anti-lice skirts. The experiment was conducted at 1 site in autumn over a 2 mo period and results relate to 1 species of cleaner fish. Our results do not mean that skirts will always reduce cleaner fish efficacy, as different circumstances may arise for other species and at other sites and times. However, given the broad use of cleaner fish $(65 \%$ of farms use cleaner fishes: Norwegian Directorate of Fisheries 2018) and widespread use of skirts (Nodland 2017, Grøntvedt et al. 2018), the effects of different in-cage anti-lice strategies should be broadly tested in space, time, and across species to see if they alter lice consumption by cleaner fish.

Regardless of anti-lice strategy, measures of the physical condition of corkwing wrasse were similar. This means that farmers could implement new strategies for lice control-specifically those that involve unfamiliar structures and feed and light regimes without high risk of harming corkwing wrasse any more than traditional sea cages.

\subsection{Delousing efficacy}

Delousing efficacy was measured in 2 ways: by counting lice in corkwing wrasse guts and estimating overall CFE for each anti-lice strategy. The poorest delousers (mean lice per gut $=0.23$ ) and the lowest CFE (-0.21) were found in lice skirt-encircled sea cages, despite extended foraging hours permitted by $24 \mathrm{~h}$ deep lights. Several explanations for this result are possible. First, echosounder data showed that salmon swam $\sim 5 \mathrm{~m}$ deeper when lice skirts were used, compared to other cages that also had deep lights and feed but no skirt; the deeper depth prefer- ence could possibly be to avoid patches of lower water quality caused by the skirt (Stien et al. 2012, Frank et al. 2015). Oldham et al. (2017) showed some avoidance of low dissolved oxygen conditions by salmon. However, it is likely that cleaner fishes mostly occupy the top $7 \mathrm{~m}$ of sea cages, to take advantage of shelter provided by hides and the observed warmest water (Brooker et al. 2018, Skiftesvik et al. 2014). Different depth distributions for salmon and cleaner fishes would lead to fewer interactions between the species and, subsequently, less lice-feeding opportunities. As different cleaner fish species demonstrate different habitat preferences (e.g. lumpsuckers avoid warm water), it may be possible to overcome the depth distribution problem by selecting species that will swim near salmon in a given farm's environment.

\subsection{Physical condition}

Corkwing wrasse physical condition was not affected by anti-lice strategies in this study, and $K$-score (1.39) was broadly similar to corkwing wrasse in previous studies (e.g. 1.34: Sayer et al. 1996, 1.43: Treasurer \& Feledi 2014). Compared to other stressors that are negative for welfare, such as capture, transfer, net-raising, and stocking (Skiftesvik et al. 2014, Treasurer \& Feledi 2014, European Union Reference Laboratory for Fish Diseases 2016), the physical modification inside a sea cage may have comparably little effect on wrasse welfare.

Across lice management strategies, $75 \%$ of corkwing had fin splits or erosion. The damage, along with skin and snout wounds, is probably due to fish capture (wild fishing and experimental) and contact with farm structures. Fin damage may also have occurred in hot water and mechanical delousing treatments (see Table S1), but further research is required to verify this observation. Severity of damage should be scored in a similar way as salmon welfare scoring (e.g. Stien et al. 2013) to study causes and development over time, environments, and treatments. Territorial fin nipping may also contribute to fin damage, although we did not observe fin nipping in video footage and nipping is rare when fish receive adequate feed (Moutou et al. 1998, Hatlen et al. 2006).

Previously, skin, eye, operculum, and snout damage in corkwing wrasse have been reported as negligible (Treasurer \& Feledi 2014). This suggests that the damage rates recorded here, especially for skin $(28 \%)$, are high. Veterinarians report 60 to $100 \%$ mortality of cleaner fishes in salmon farms (Olsen 
2017), at least $33 \%$ of which occurs within 5 mo after stocking (Nilsen et al. 2014). It is likely that external injuries and disease cause high mortality, but methods to measure welfare, mortality, and escapees need to be improved. Nevertheless, by law, fish housed in sea cages must be treated to the same ethical standard as salmon (Norwegian Seafood Research Fund 2018). To meet this ethical requirement, and given the recent and rapid expansion in cleaner fish use (Norwegian Directorate of Fisheries 2018), there is an urgent need to advance, validate, and oversee implementation of industry recommendations (Norwegian Seafood Research Fund 2018) across Norway to secure cleaner fish welfare via a verified and measurable standard for 'healthy' cleaner fishes in sea cages. Without this benchmark, we cannot extrapolate our findings beyond this specific site, season, and species.

\subsection{Gut contents}

Across all anti-lice strategies, corkwing wrasse consumed similar but highly varied diets that included algae, crustaceans, fish feed, and salmon lice. The only difference was that wrasse in the cleaner fish plus functional feed treatment ate fewer crustaceans compared to all other strategies. Crustacea were generally Caprellid amphipods, which are abundant on salmon farm nets (Blöcher 2013), so corkwing wrasse would have many opportunities to reach optimal prey handling efficiency for this food item (Warburton 2003). Lice, however, are not reliable food sources on salmon farms as loads usually remain below 0.5 adult female lice per salmon. Thus, cleaner fishes would have had fewer opportunities to learn delousing behaviours and it would take longer to reach optimal prey handling efficiency of lice. The proportion of caprellids in gut contents was greatest in cages with skirts. Caprellids may have been more abundant in cages with lice skirts, as skirts create an area of reduced flow immediately behind the skirt wall, which may promote biofouling and Caprellid abundance.

\subsection{Behaviour}

In $>600$ min of video, lice feeding was recorded 6 times by 4 cleaner fish, indicating that cleaner fishsalmon interactions are rare and hard to capture on film in this setting. We detected no differences in the suite of behaviours performed by cleaner fishes among anti-lice strategies. Therefore, the differences observed in lice per gut and CFE likely reflect different encounter rates between salmon and cleaner fishes induced by the different anti-lice strategies.

\subsection{Industry implications}

Although focusing on only one species of cleaner fish in autumn, this work emphasises the importance of full-scale studies, where complex interactions between farm routines, environmental conditions, and cage technologies likely affect cleaner fish efficacy. A clear recommendation arising from this work is that aquaculture production managers should test new technologies across seasons and sites for interactions with cleaner fish performance. This will enable fine-tuning of cleaner fish deployment strategies to optimise their efficacy.

In this commercial-scale experiment, lice skirts impaired the delousing efficacy of corkwing wrasse. This likely occurred due to skirts creating a spatial mismatch between where corkwing (shallower at hide depths of 0 to $7 \mathrm{~m}$ ) and salmon (deeper with an average swimming depth of $11 \mathrm{~m}$ ) occurred in cages, which reduced the encounter rate between cleaners and salmon. If new technologies create a mismatch between cleanerfish swimming depths and salmon swimming depths, then strategies such as adjustments to hide depths could reduce this difference if cleaners follow hides deeper. Different species of cleaner fish may also have clear vertical preferences that can be used in co-management with prevention technologies. An example is the semi-pelagic nature of lumpsucker compared to the more bottomdwelling wrasse, or the temperature tolerance of different species. If further research reveals that specific lice-prevention technologies consistently compromise the interactions of cleaner fish with salmon and reduce lice-feeding opportunities, periods of non-use of cleaner fish may prove the best strategy.

Salmon lice made up $<2 \%$ of the diet of corkwing wrasse, and only $11 \%$ of guts contained salmon lice. Increasing the number of cleaners that engage in feeding behaviour and the frequency with which they engage should be a priority for cleaner-fish managers. If research can identify high-performing cleaner fish and transfer their behaviour to other individuals via selective breeding programs (e.g. lumpsuckers; Imsland et al. 2016) or through specific acclimation measures, such as pre-exposing cleaner fish to lice-infected salmon in small enclosures or providing live Artemia and frozen lice as feed before 
they are stocked in full-scale sea cages (e.g. Gentry 2018, Imsland et al. 2019), then cleaner fishes could become more effective biological control agents. If corkwing wrasse welfare and efficacy cannot be improved, the industry may need to reconsider its use of this species as a biological control agent.

Acknowledgements. We thank staff at the Vindsvik CAC and Mowi including Henrik Trengereid, Agnes Kleppa, and Unni Austefjord for on-site facilitation and technical assistance. We thank technical and field staff from the Institute of Marine Research, including Velimir Nola and Simon Flavell. Funding was provided by the Norwegian Seafood Research Fund (project 901243) and the Research Council of Norway for the 'Future Welfare' project (\#267800).

\section{LITERATURE CITED}

Aaen SM, Helgesen KO, Bakke MJ, Kaur K, Horsberg TE (2015) Drug resistance in sea lice: a threat to salmonid aquaculture. Trends Parasitol 31:72-81

Bjordal Å (1988) Cleaning symbiosis between wrasse (Labridae) and lice infested salmon (Salmo salar) in mariculture. Int Counc Explor Sea 188:1-8

Bjordal Å, Juell JE, Lindem T, Fernö A (1993) Hydroacoustic monitoring and feeding control in cage rearing of Atlantic salmon (Salmo salar L.). In: Reinertsen H, Dahle LA, Jørgensen L, Tvinnereim K (eds) Fish farming technology. Balkema, Trondheim, p 203-208

Blöcher N (2013) Biofouling in the Norwegian salmon farming industry. PhD thesis, Norwegian University of Science and Technology, Trondheim

Bolton-Warberg M (2018) An overview of cleaner fish use in Ireland. J Fish Dis 41:935-939

*Booker A, Papadopoulou A, Gutiérrez C, Rey S, Davie A, Migaud H (2018) Sustainable production and use of cleaner fish for the biological control of sea lice: recent advances and current challenges. Vet Rec 183:383

Costello MJ (2006) Ecology of sea lice parasitic on farmed and wild fish. Trends Parasitol 22:475-483

Darwall W, Costello M, Lysaght S (1992) Wrasse-How well do they work? Aquacult Irel 50:26-29

Deady S, Varian SJA, Fives JM (1995) The use of cleanerfish to control sea lice on two Irish salmon (Salmo salar) farms with particular reference to wrasse behaviour in salmon cages. Aquaculture 131:73-90

* Dempster T, Korsoen Ø, Oppedal F, Folkedal O, Juell JE (2009) Submergence of Atlantic salmon (Salmo salar) in sea-cages: a potential short-term solution to poor surface conditions. Aquaculture 288:254-263

Eliasen K, Danielsen E, Johannesen Á, Joensen LL, Patursson EJ (2018) The cleaning efficacy of lumpfish (Cyclopterus lumpus) in Faroese salmon (Salmo salar) farming pens in relation to lumpfish size and seasonality. Aquaculture 488:61-65

European Union Reference Laboratory for Fish Diseases (2016) Cleaner fish in aquaculture: Health management and legislative issues. European Union Reference Laboratory for Fish Diseases, Copenhagen

Fast MD (2014) Fish immune responses to parasitic copepod (namely sea lice) infection. Dev Comp Immunol 43: 300-312
FHF (2016) Program rensefisk: oppdatering av rensefiskveiledere. Norwegian Seafood Research Fund. http://fhf. no/prosjektdetaljer/?projectNumber $=901258$ (accessed 14 Nov 2019)

Frank K, Gansel LC, Lien AM, Birkevold J (2015) Effects of a shielding skirt for prevention of sea lice on the flow past stocked salmon fish cages. J Offshore Mech Arctic Eng 137:011201

Frenzl B, Stien LH, Cockerill D, Oppedal F and others (2014) Manipulation of farmed Atlantic salmon swimming behaviour through the adjustment of lighting and feeding regimes as a tool for salmon lice control. Aquaculture 424-425:183-188

Gentry K (2018) Anti-lice strategies affect cleaner fish delousing efficacy. MSc thesis, University of Melbourne

Grøntvedt RN, Kristoffersen AB, Jansen PA (2018) Reduced exposure of farmed salmon to salmon louse (Lepeophtheirus salmonis L.) infestation by use of plankton nets: Estimating the shielding effect. Aquaculture 495: 865-872

Gulla S, Bornø G (2018) The health situation in cleaner fish. In: The health situation in Norwegian aquaculture 2018. Norwegian Veterinary Institute (Veterinaerinstituttet) 1b, p 97-101

*Hamre LA, Bui S, Oppedal F, Skern-Mauritzen R, Dalvin S (2019) Development of the salmon louse Lepeophtheirus salmonis parasitic stages in temperatures ranging from 3 to $24^{\circ} \mathrm{C}$. Aquacult Environ Interact 11:429-443

*Hatlen B, Grisdale-helland B, Helland SJ (2006) Growth variation and fin damage in Atlantic cod (Gadus morhua L.) fed at graded levels of feed restriction. Aquaculture 261:1212-1221

*Hersoug B (2015) The greening of Norwegian salmon production. Marit Stud 14:1-19

Imsland AK, Reynolds P, Eliassen G, Hangstad TA, Foss A, Vikingstad E, Elvegård TA (2014) The use of lumpfish (Cyclopterus lumpus) to control sea lice (Lepeophtheirus salmonis) infestations in intensively farmed Atlantic s almon (Salmo salar). Aquaculture 424-425:18-23

* Imsland AK, Reynolds P, Eliassen G, Hangstad TA and others (2015) Feeding preferences of lumpfish (Cyclopterus lumpus) maintained in open net-pens with Atlantic salmon (Salmo salar). Aquaculture 436:47-51

Imsland AK, Reynolds P, Eliassen G, Mortensen A and others (2016) Is cleaning behaviour in lumpfish (Cyclopterus lumpus) parentally controlled? Aquaculture 459:156-165

Imsland AKD, Hanssen A, Nytrø AV, Reynolds P and others (2018) It works! Lumpfish can significantly lower sea lice infestation in large-scale salmon farming. Biol Open 7: bio036301

炎Imsland AKD, Frogg N, Stefansson SO, Reynolds P (2019) Improving sea lice grazing of lumpfish (Cyclopterus lumpus L.) by feeding live feeds prior to transfer to Atlantic salmon (Salmo salar L.) net-pens. Aquaculture 511: 734224

Jensen L, Provan F, Larssen E, Bron J, Obach A (2015) Reducing sea lice (Lepeophtheirus salmonis) infestation of farmed Atlantic salmon (Salmo salar L.) through functional feeds. Aquacult Nutr 21:983-993

Korsøen Ø, Dempster T, Fjelldal PG, Kristiansen T, Oppedal F (2009) Long-term submergence of Atlantic salmon (Salmo salar L.) during winter affects behaviour, growth and condition. Aquaculture 296:373-381

K Krkošek M, Revie CW, Gargan PG, Skilbrei OT, Finstad B, Todd CD (2013) Impact of parasites on salmon recruit- 
ment in the Northeast Atlantic Ocean. Proc R Soc B 280: 20122359

Leclercq E, Davie A, Migaud H (2014) Delousing efficiency of farmed ballan wrasse (Labrus bergylta) against Lepeophtheirus salmonis infecting Atlantic salmon (Salmo salar) post-smolts. Pest Manag Sci 70:1274-1282

Lenth R (2016) Least-squares means: the R Package lsmeans. J Stat Soft 69:1-33

Liu Y, Bjelland H (2014) Estimating costs of sea lice control strategy in Norway. Prev Vet Med 117:469-477

Loew E, Skiftesvik AB, Bjelland R, Browman H, Durif C (2016) Spectral sensitivity and contrast potentials for four species of cleaner fish. Institute of Marine Research 39-2016. Havforskningsinstituttet, Bergen

*Moutou K, McCarthy I, Houlihan D (1998) The effect of ration level and social rank on the development of fin damage in juvenile rainbow trout. J Fish Biol 52: 756-770

Munro LA, Wallace IS (2017) Scottish Fish Farm Production Survey 2016. Marine Scotland Science. The Scottish Government, Edinburgh

Munro LA, Wallace IS (2018) Scottish Fish Farm Production Survey 2017. Marine Scotland Science. The Scottish Government, Edinburgh

Nilsen A, Viljugrein H, Røsæg MV, Colquhoun D (2014) Rensefiskhelse - kartlegging av dødelighet og dødelighetsårsaker. Veterinærinstituttets rapportserie 12-2014. Veterinærinstituttet, Oslo

Nilsen A, Nielsen KV, Biering E, Bergheim A (2017) Effective protection against sea lice during the production of Atlantic salmon in floating enclosures. Aquaculture 466: 41-50

Nodland E (2017) Har levert luseskjørt tilsvarende 110 fotballbaner. iLaks.no. https://ilaks.no/har-levert-luseskjorttilsvarende-110-fotballbaner/ (accessed 9 May 2019)

Norwegian Directorate of Fisheries (2018) Cleanerfish (Lumpfish and Wrasse). www.fiskeridir.no/English/Aquaculture/ Statistics/Cleanerfish-Lumpfish-and-Wrasse (accessed 14 Nov 2019)

Norwegian Seafood Research Fund (2018) FHF cleaner fish guidelines (in English). FHF. http://scottishaquaculture. com/knowledge/knowledge-exchange/ (accessed 14 Nov 2019)

Oldham T, Dempster T, Fosse JO, Oppedal F (2017) Oxygen gradients affect behaviour of caged Atlantic salmon Salmo salar. Aquacult Environ Interact 9: $145-153$

Olsen S (2017) Næringen trenger ikke enda flere å spise wienerbrød med, de trenger rett og slett også litt tyggemotstand. iLaks.no. https://ilaks.no/naeringen-trengerikke-enda-flere-a-spise-wienerbrod-med-de-trengerrett-og-slett-ogsa-litt-tyggemotstand/ (accessed 14 Nov 2019)

Oppedal F, Dempster T, Stien L (2011) Environmental drivers of Atlantic salmon behaviour in sea-cages: a review. Aquaculture 311:1-18

Oppedal F, Samsing F, Dempster T, Wright DW, Bui S, Stien LH (2017) Sea lice infestation levels decrease with deeper 'snorkel' barriers in Atlantic salmon sea-cages. Pest Manag Sci 73:1935-1943

* Overton K, Dempster T, Oppedal F, Kristiansen T, Gismervik K, Stien L (2019) Salmon lice treatments and salmon mortality in Norwegian aquaculture: a review. Rev Aquacult 11:1398-1417

* Overton K, Barrett L, Oppedal F, Kristiansen T, Dempster T
(2020) Sea lice removal by cleaner fish in salmon aquaculture: a review of the evidence base. Aquacult Environ Interact 12:31-44

Quignard JP, Pras A (1986) Labridae in fishes of the Northeastern Atlantic and the Mediterranean. UNESCO, Paris

R Core Team (2018) R: a language and environment for statistical computing. R Foundation for Statistical Computing, Vienna

Samsing F, Oppedal F, Dalvin S, Johnsen I, Vågseth T, Dempster T (2016) Salmon lice (Lepeophtheirus salmonis) development times, body size, and reproductive outputs follow universal models of temperature dependence. Can J Fish Aquat Sci 73:1841-1851

Samsing F, Johnsen I, Dempster T, Oppedal F, Treml EA (2017) Network analysis reveals strong seasonality in the dispersal of a marine parasite and identifies areas for coordinated management. Landscape Ecol 32: 1953-1967

Sayer M, Gibson R, Atkinson R (1996) Growth, diet and condition of corkwing wrasse and rock cook on the west coast of Scotland. J Fish Biol 41:76-94

Sayer M, Reader J (1996) Exposure of goldsinny, rock cook and corkwing wrasse to low temperature and low salinity: survival, blood physiology and seasonal variation. J Fish Biol 49:41-63

* Skiftesvik AB, Bjelland RM, Durif CMF, Johansen IS, Browman HI (2013) Delousing of Atlantic salmon (Salmo salar) by cultured vs. wild ballan wrasse (Labrus bergylta). Aquaculture 402-403:113-118

Skiftesvik AB, Blom G, Agnalt AL, Durif CMF and others (2014) Wrasse (Labridae) as cleaner fish in salmonid aquaculture - The Hardangerfjord as a case study. Mar Biol Res 10:289-300

Skiftesvik AB, Durif CMF, Bjelland RM, Browman HI (2015) Distribution and habitat preferences of five species of wrasse (Family Labridae) in a Norwegian fjord. ICES J Mar Sci 72:890-899

* Stien LH, Nilsson J, Hevrøy EM, Oppedal F, Kristiansen TS, Lien AM, Folkedal O (2012) Skirt around a salmon sea cage to reduce infestation of salmon lice resulted in low oxygen levels. Aquacult Eng 51:21-25

Stien LH, Bracke MCM, Folkedal O, Nilsson J and others (2013) Salmon Welfare Index Model (SWIM 1.0): a semantic model for overall welfare assessment of caged Atlantic salmon: review of the selected welfare indicators and model presentation. Rev Aquacult 5:33-57

Stien LH, Dempster T, Bui S, Glaropoulos A, Fosseidengen JE, Wright DW, Oppedal F (2016) 'Snorkel' sea lice barrier technology reduces sea lice loads on harvest-sized Atlantic salmon with minimal welfare impacts. Aquaculture 458:29-37

Stien LH, Lind MB, Oppedal F, Wright DW, Seternes T (2018) Skirts on salmon production cages reduced salmon lice infestations without affecting fish welfare. Aquaculture 490:281-287

Treasurer JW (2013) Use of wrasse in sea lice control (SARF068). Scottish Aquaculture Research Forum, Pitlochry

Treasurer JW (2018) Cleanerfish biology and aquaculture applications. 5m Publishing, Sheffield

* Treasurer J, Feledi T (2014) The physical condition and welfare of five species of wild-caught wrasse stocked under aquaculture conditions and when stocked in Atlantic 
salmon, Salmo salar, production cages. J World Aquacult Soc 45:213-219

Tully O, Daly P, Lysaght S, Deady S, Varian SJA (1996) Use of cleaner-wrasse (Centrolabrus exoletus (L.) and Ctenolabrus rupestris (L.)) to control infestations of Caligus elongatus Nordmann on farmed Atlantic salmon. Aquaculture 142:11-24

Warburton K (2003) Learning of foraging skills by fish. Fish Fish 4:203-215

Editorial responsibility: Kevin Glover, Bergen, Norway
Werkman M, Green DM, Murray AG, Turnbull JF (2011) The effectiveness of fallowing strategies in disease control in salmon aquaculture assessed with an SIS model. Prev Vet Med 98:64-73

*Yuen JW, Dempster T, Oppedal F, Hvas M (2019) Physiological performance of ballan wrasse (Labrus bergylta) at different temperatures and its implication for cleaner fish usage in salmon aquaculture. Biol Control 135:117-123

Submitted: May 10, 2019; Accepted: December 17, 2019 Proofs received from author(s): February 12, 2020 